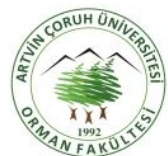

\title{
Orman ürünleri sanayi sektöründe iş kazası ve ölümlü iş kazalarının Türkiye ve Avrupa Birliği ülkeleri düzeyinde incelenmesi
}

\section{Investigation of occupational accident and fatal occupational accidents in forest products sector at the level of Turkey and the European Union countries}

\author{
Kadri Cemil AKYÜZ1 ${ }^{1 D}$, ibrahim YILDIRIM ${ }^{1}$ iD , ilker AKYÜZ $^{1}$ (D) Nadir ERSEN $^{2}$ \\ ${ }^{1}$ Orman Endüstri Mühendisliği Bölümü, Orman Fakültesi, Karadeniz Teknik Üniversitesi, Trabzon-Türkiye \\ 2 Ormancılık Bölümü, Artvin Meslek Yüksekokulu, Artvin Çoruh Üniversitesi, Artvin-Türkiye
}

\section{Eser Bilgisi / Article Info}

Araştırma makalesi / Research article

DOI: 10.17474/artvinofd.509138

Sorumlu yazar / Corresponding author

Kadri Cemil Akyüz

e-mail: akyuz@ktu.edu.tr

Geliş tarihi / Received

07.01.2019

Düzeltme tarihi / Received in revised form

16.09.2019

Kabul Tarihi

30.09.2019

Elektronik erişim / Online available

30.10.2019

\section{Anahtar kelimeler:}

Orman ürünleri sanayi

İş kazası

Ölümlü iş kazası

\section{Keywords:}

Forest products industry

Occuptional accident

Fatal occuptional accident

\begin{abstract}
Özet
Üretim teknolojilerinde meydana gelen değişim, daha düşük maliyetle daha fazla üretim yapma isteği ve firmaların farklılaşan pazar koşullarında ayakta kalma zorunluluğu çalışma ortamlarında iş sağlığı ve güvenliği açısından sorunları beraberinde getirmektedir. Gelişmiş ve gelişmekte olan ekonomiler iş kazaları ve iş kazalarına bağlı oluşan ölümlerin azaltılması için farklı yasal düzenlemeler yapmakta ve çalışan güvenliğini ön plana çıkarmaya çalışmaktadır. Ülkemizde bu alanda yapılan yasal düzenlemelerin önemli bir kısmı Avrupa Birliğine ( $A B$ ) adaylık sürecinde oluşturulan uyum yasaları çerçevesinde çıkarılmıştır. Yapılan yasal düzenlemelerin sektörel boyutta nasıl sonuçlar verdiğinin belirlenmesinin amaçlandığı bu çalışmada orman ürünleri sanayi sektörünü oluşturan üç alt sektörel yapının Türkiye ve $A B$ üyeleri ülkeleri düzeyinde karşılaştırılması hedeflenmiştir. 2008-2017 yılları kapsamında ülkemiz ve $A B$ üyesi ülkelerde meydana gelen iş kazası ve ölüm rakamlarının istatistiksel açıdan incelendiği çalışmada özellikle 2013 yılında yürürlüğe giren 6331 sayılı yasanın etkileri sorgulanmıştır. Çalışma sonucunda $A B$ genelinde tüm sektörel boyutlarda iş kazası ve ölüm rakamlarında oluşan azalma karşısında ülkemizde incelenen yıllar düzeyinde sürekli artışların yaşandığı belirlenmiştir. Çıkarılan ve uygulamaya çalışılan yasal düzenlemelerin yeterli olmadığı ve güvenlik kültürünün oluşumuna yönelik çalışmaların yoğunlaştırılmasının zorunlu olduğu tespit edilmiştir.
\end{abstract}

\begin{abstract}
The change in production technologies, the desire to produce more at lower costs and the necessity of firms to survive in different market conditions bring problems in terms of occupational health and safety in working environments. Developed and developing economies regulate different laws to reduce occuptional accidents and occuptional accident deaths and it is trying to highlight employee safety. In our country, a significant part of the legal regulations in this sector has been enacted within the framework of the harmonization laws established in the process of candidacy to the European Union (EU). In this study, which it is aimed to determine how the legal regulations of sectoral scale give results, it was aimed that three sub-sectoral structures of the forest products industry sector were compared in the Turkey and EU countries level. In the study which examined the occuptional accident and death figures that occurred in our country and EU member countries within the period of 20082017, the effects of Law No. 6331, which entered into force in 2013, have been investigated. As a result of the study, it has been determined that there has been a decrease in the number of work accidents and deaths in all sectoral dimensions throughout the EU, while there have been continuous increases in the level of years examined in our country. It has been determined that the legislative regulations adopted and implemented are not sufficient and the efforts for the formation of the security culture should be intensified.
\end{abstract}

\section{Giriş}

Farklılaşan ve değişim gösteren istek ve ihtiyaçları karşılaması amacıyla, üretim teknolojilerinde oluşturulan yenilikler iş sağlığı ve güvenliğine yönelik endişeleri de beraberinde getirmektedir. Daha fazla üretimin daha düşük maliyetlerle gerçekleştirilmesi amacıyla üretim süreçlerinin tüm aşamalarında oluşturulan hızlı değişim ve yenilenme isteği iş kazaları ve çalışanların sorunlarla karşılaşmasını kaçınılmaz hale getirmektedir. Doğada toplayıcılık yaparak ihtiyaçlarını karşılama amacı güden insana yönelik kullanılan iş kazası kavramı ile günümüz modern çalışma ortamı içinde farklı sorunlarla mücadele 
eden çalışanların iş kazası kavramları arasında kıyaslanmayacak farklar bulunmaktadır.

Çalışanların bulundukları üretim ortamlarında zorunlu olan sağlık koşullarının temin edilerek çalıştırımaları amacıyla yapılmış olan birçok yasal ve hukuksal düzenlemeler olmasına karşın iş kazası ve ölüm rakamları gelişmiş ülkeler genelinde bile oldukça yüksek seviyelerdedir. İçinde bulunduğumuz yüzyıl içinde çalışma ortamından kaynaklı olan sorunlar nedeni ile yılda ortalama 2.7 milyon insan ölmekte, 2 milyon kişi meslek hastalı̆ına yakalanmaktadır (Öçal ve Çiçek 2017). Kazaların önlenmesi aşamasında karşılaşılan ekonomik boyut ve kaza sonrası ortaya çıkan ekonomik sorunlar arasında oluşan dengesizlik kaza önleme amacıyla yapılacak çalışmaların daha önemli olduğunu göstermektedir. Sürekli gelişim içinde olan kaza önlenmesine yönelik tedbirler bütünü teknolojik ve ekonomik büyüklükle bağlantılı bir değişim göstermektedir. Gelişmişlik göstergelerinden olan ekonomik-sosyal koşullar ve sendikal haklar dikkate alındığında, gelişmiş ülkelerin kazaların önlenmesi için aldıkları tedbir ve önlemler diğer ülkelere göre daha kolay ve uygulanabilir olacaktır. Ülkemizde ise yapılmış olan birçok hukuksal düzenlemeye rağmen iş kazası ve ölüm sayıları oldukça yüksektir. Özellikle kuralların uygulanmasında yaşanan sorunlar ve hukuksal mevzuatın yerine getirilmemesinden dolayı çalışanlar iş güvenliği kurallarına uygun çalışma ortamlarından yoksun kalmaktadır. Ülkemizin Avrupa Birliğine adaylık süreci boyunca bu alanda yaşamakta olduğu eksikliklerin giderilmesi ve Avrupa Birliği müktesebatına uygun bir yapı elde edilmesi amacıyla 2012 yılında çıkarılan ve 2013 yılında yürürlüğe giren 6331 sayılı iş Sağlığı ve Güvenliği Kanunu ile eksikliklerin giderilmesi amaçlanmıştır. Bu kanun kapsamında 155 ve 161 sayılı sözleşmeler ve 89/391 EEC sayılı AB çerçeve direktiflerinin gerekliliği olarak ulusal bir iş sağlığı ve güvenliği mevzuatının çıkarılması sağlanmıştır (Korkmaz ve Avsallı 2012). Hukuksal düzenlemelerin yapılmış olmasına karşın iş yeri ve çalışan düzeyinde konunun yeterli düzeyde önemsenmemesi ve tedbirlerin uygulanmasında oluşan mevzuat eksiklikleri bu alanda oluşan sorunların giderilmesinde eksiklikler oluşturmuştur.
İs kazalarının önlenebilmesi kazaya neden olan ortamların ve üretim yapılan sektörel birimlerin özel olarak değerlendirilmesi ile mümkün olabilecektir. Kazaların önemli bir kısmının madencilik, inşaat ve imalat sanayi alanlarında gerçekleşmiş olması bu alanların ayrıntılı bir biçimde incelenmesini gerekli kılmaktadır (Üçüncü 2015; Erginel ve Toptancı 2017). Her sektörün kendine özel koşulların ve çalışan profilinin dikkate alınması alınacak önlem ve yasal düzenlemelerin daha sağlıklı uygulanmasına imkan tanıyacaktır. Sahip olduğu ürün özellikleri nedeni ile birçok kesici, ezici ve parçalayıcı ekipman ile çalışımasının zorunlu olduğu orman ürünleri sanayi sektörü imalat sanayi içinde üç farklı alt bölümle temsil edilmektedir (Ağaç, ağaç ürünleri ve mantar imalatı; Kağıt ve kağıt ürünleri imalatı; Mobilya imalatı). İmalat sanayi içerisinde işyeri toplam sayısının yaklaşık \%20'sini oluşturan orman ürünleri sanayi sektörü oluşturmaktadır (Akyüz 1995). Bu sektör genelinde sahip olunan teknolojik çeşitliliği ve üretilen ürünlerin sayısal çokluğu üretim yapan binlerce vasıflı ve vasıfsız çalışan ile birleşince risk ve kaza analizlerinin yapılmasını ve gereken düzeltici tedbirlerin alınmasını zorunlu kılmaktadır.

Çalışmamızda imalat sanayi içinde yer alan orman ürünleri sanayi sektörünün Türkiye ve Avrupa Birliği ülkeleri düzeyinde iş kazası ve ölüm düzeyleri bakımından hangi seviyelerde olduğunun tartışıması amaçlanmıştır. Özellikle Avrupa Birliğine adaylık sürecinde sektörel olarak iş kazası ve ölüm seviyelerinin Avrupa Birliğine üye ülkeler ile karşılıklı olarak değerlendirilmesi ve ülkemizin bu alandaki konumunun irdelenmesi hedeflenmiştir.

\section{İş Sağlığı ve İş Güvenliği (isG)}

Çalışma hayatında özellikle 1980 'li yıllardan sonra yoğun olarak kullanılmaya başlayan iş sağlığı ve güvenliği, yapılan işin yürütülmesi sürecinde çalışan sağlığına zarar verebilecek olan koşulların ortadan kaldırılması ve çalışma ortamların düzenlenmesi amacıyla yapılacak olan çalışmaları tanımlamak için kullanılan kavramlar bütününü oluşturmaktadır. İş sağlığı, çalışanı olumsuz yönde etkilemesi muhtemel, çalışma ortamından veya yapılan işten kaynaklı olarak meydana gelebilecek her türlü tehlikeden korunma halini ifade etmekte olup insan sağlığı ile doğrudan bağıntılı olması sebebi ile de doğuştan 
gelen haklar arasında yer almaktadır. iSG hizmetleri kavramı kapsayıcı olması adına, bir işyerinde çalışan kişilerin sağlık ve güvenlik yönünden korunmuşluğunu ve kullanılan materyallerin çalışabilirliğini sağlamak ve bu durumu sürdürmek adına gösterilen her türlü sistemli çalışmanın genel adı olarak belirtilmektedir (Tülü 2014). Farklı birçok disiplinin bir arada faaliyet göstermesini gerektiren isG çalışanların, üretimin ve işletmenin güvenliğini sağlamak amaçlarını taşıyan bir yapıya sahiptir.

Tarihsel süreç içinde iş sağlığı ve güvenliğine yönelik birçok çalışma yapılmış ve hukuki önlemler alınmaya çalışılmıştır. Başlangıçta işyerlerinde sağlıklı ve güvenilir çalışma ortamının oluşturulması amacını taşıyan bu düzenlemeler daha sonra iş sağlığı ve güvenliği kavramları üzerine yoğunlaşmıştır.

$\mathrm{Bu}$ alanda iş sağlığı ve güvenliğine yönelik kayıtlı ilk belge Heredot tarafından hazırlanan ve çalışanların beslenme gereklilikleri üzerine oluşturmuş olan belgedir. Uluslararası alanda geçerliliği olan son belge ise 1999 yılında mesleki sağlık ve emniyet idare sistemleri için düzenlenen OHSAS 18001'dir (Şahin 2010). Ülkemiz tarihine 1865'li yıllarda Dilaver Paşa Nizamnamesi ile çalışanın korunması amacıyla giren iSG uygulamaları, 1 Ocak 2013 tarihinde yürürlüğe giren 6331 sayılı iş sağlığı ve güvenliği kanunu ile modern yapısına kavuşmuştur. İ̧̧ sağlığı ve güvenliğine yönelik olarak uluslararası alanda söz sahibi olan Dünya Sağlık Örgütü (WHO) ve Uluslararası Çalışma Örgütü (ILO) işyerlerinde çalışanlara yönelik olabilecek tüm sağlık sorunlarını iş sağlığı kapsamında değerlendirmekte, tüm çalışanların korunmasına yönelik düzenlemeler oluşturmakta, insana yakışır işlerin yapılması ve insana yakışır kazançlar elde edilmesi ilkesini benimsemektedir (Hsu 2011). Sosyal devlet olmanın temel gereklerinden olan iş sağlığı ve güvenliği kavramı işçilerin sağlık ve güvenlik koşullarına uygun çalışma ortamlarının temin edilmesini talep eden bir yapı içinde bulunmaktadır. Bu alandaki düzenlemeler yaşam ve sağlık hakkının yaşama geçirilmesinde önemli bir adım niteliğindedir (Süzek 1985).

\section{İş Kazası}

Sanayi devrimi ile makineleşmenin artması sonucu kaza risklerinde meydana gelen yükselme iş kazası kavramının literatüre girmesine neden olmuştur. İlk kez 19. yüzyıl sonlarında ortaya çıkan iş kazası kavramı Almam imparatorluğuna ait fabrikalarda çalışan iş̧̧ilerin iş kazası ve çalışma risklerine karşı korunması amacıyla zorunlu sigorta sisteminin başlatılması ve işçinin zararının karşılanması gerekliliği ile gündeme gelmiştir (Koçer 2014; Güzel ve ark. 2016). Ülkemizde 5510 sayılı Sosyal Sigortalar ve Genel Sağlık Sigortası Kanunu'nun 13'üncü maddesinde yer alan iş kazası kavramı ile oldukça geniş kapsamlı bir iş kazası tanımı öngörülmüş; işyerinde gerçekleşen tüm zarar verici olaylar, yürütülen işle ilgili olsun ya da olmasın, iş kazası sayılmıştır (Yılmaz 2017).

ILO' ya göre önceden planlanmamış, bilinmeyen ve kontrol altına alınamamıs olan etrafa zarar verebilecek nitelikteki olay olarak tanımlanan iş kazası, WHO tanımlamasında ise önceden planlanmamış kişisel yaralanmalara, maddi zarar ve üretimin durmasına sebep veren olay olarak ifade edilmektedir. Avrupa Birliği İstatistik Ofisi (EUROSTAT) ise iş kazasını işin gerçekleşmesi sırasında fiziksel ve ruhsal zarara yol açan ani bir olay olarak tanımlamaktadır (Kılkış 2016). Ulusal mevzuat açısından 6331 sayılı İ̧ Sağığı ve Güvenliği Kanununda iş kazası "iş yerinde veya işin yürütümü nedeniyle meydana gelen, ölüme sebebiyet veren veya vücut bütünlüğünü ruhen ya da bedenen özre uğratan olay" olarak tanımlanmaktadır (Korkut ve Tetik 2013). İş kazası 5510 sayılı Sosyal Sigortalar ve Genel Sağlık Sigortası Kanununda ise "sigortalı bireyin işyerinde bulunduğu esnada işveren tarafından yürütülmekte olan işten kaynaklı olarak sigortalı bireyin görevli olarak işyeri dışında başka bir yere gönderilmesi dolayısıyla asıl işini yapmadan geçen zamanlarda, emziren sigortalı bireyin çocuğuna süt vermek için ayrılan zamanlarda, sigortalı bireyin işveren tarafından sağlanan bir taşıt aracılığıyla işin gerçekleştiği yere gidiş gelişleri süresinde, kendi hesabına bağımsız çalışan sigortalı bireyin işyerinde bulunduğu esnada ya da yürütmekte olduğu iş dolayısıyla işyerinin dışında meydana gelen ve sigortalı bireyi anında ya da sonradan bedenen ve ruhen zarara uğratan olay" şeklinde tanımlanmaktadır (Erginel ve Toptancı 2017; SGK 2018). 6331 sayılı kanun iş kazasına maruz kalan kişiyi sınırlandırmış ve işyerinde ya da işin yürütülmesi sırasında 
olan olayı iş kazası olarak tanımlamış ve olayın işyerinde meydana gelmesini yeterli görmüştür. 5510 sayılı kanun ise sigortalı üzerinden değerlendirme yapmış ve çalışma süresinde sayılan durumları da ifade etmiştir. Ayrıca işin yapıldığı yere geliş ve gidişleri ve bu süre zarfında olabilecek olayları da iş kazası tanımlaması içine almıştır.

\section{MATERYAL ve YÖNTEM}

Gerek $A B$ öncesi ve gerekse uyum yasaları kapsamında yapılmış olan yasal düzenlemeler ülkemizde iş kazaları ve oluşan ölüm oranlarının azaltılması konusunda yeterli katkıyı sağlayamamıştır. Bu anlamda özellikle ülke şartları gereği oluşan sosyo-ekonomik sorunlar, hızlı sanayileşme isteği sonucunda ortaya çıkan problemler, çalışanların eğitim yetersizlikleri ve alınan tedbirlere olumsuz bakış açıları, iş sağlığı ve güvenliği alanında yetişmiş yeterli ve deneyimli çalışan eksikliği, işletmelerin ve yöneticilerin mevzuatlara uyma noktasında özellikle ekonomik endişe kaynaklı eksiklikleri, küçük ölçekli işletmelerin yapısal yetersizlikleri ve denetim sorunları iş kazası ve ölüm rakamlarının azaltılması konusunda yetersiz kalınmasına neden olmuştur.

Ülkemizin AB sürecinde özellikle 2013 yılında uygulamaya alınan 6331 sayılı yasa kapsamında iş sağ lığı ve güvenliği açısından nasıl bir konumda bulunduğunun oluşan iş kazaları ve ölüm sayıları kapsamında irdelenmesinin hedeflendiği çalışma 2008-2017 yılları genelinde oluşan değişimin belirlenmesi amacıyla gerçekleştirilmiştir. Bu amaçla özellikle imalat sanayi kapsamında ve Orman Ürünleri Sanayi alt sektörleri düzeyinde Türkiye ve Avrupa Birliği ülkelerinin iş kazası ve ölüm rakamlarının yıllar kapsamında irdelenmesi amaçlanmıştır. Avrupa Birliği İstatistik Ofisi (2018) ve Sosyal Güvenlik Kurumu (2018) veri tabanlarından elde edilen yıllık verilerin analizi yardımıyla gerek ülkemiz imalat ve orman ürünleri sanayi sektörlerinde ve gerekse $A B$ ülkeleri imalat ve orman ürünleri sanayi sektörlerinde oluşan değişimlerin değerlendirilmesi hedeflenmiştir.

\section{BULGULAR}

\section{Türkiye'de İş Kazası ve ölüm}

Türkiye'de 2017 yılı Aralık ayı itibariyle toplam çalışan sayısı 27727600 civarındadır (Eurostat 2018). Tüm çalışanlar 6331 sayılı kanun kapsamında iş sağlığı ve güvenliği şemsiyesi altında çalışmaktadır. Ülkemizde iş kazası ve kazalar sonucu gerçekleşen ölümlere yönelik istatistikler SGK tarafından tutulmaktadır. 2008 ve 2017 yılları arasında ülkemiz genelinde meydana gelen iş kazaları ve iş kazalarına bağlı ölümlere ait veriler Çizelge 1 'de görülmektedir.

Çizelge 1. Türkiye'de 2008-2017 yılları arasında meydana gelen iş kazaları ve ölümler

\begin{tabular}{ccccccc}
\hline & \multicolumn{3}{c}{ Toplam İş Kazası } & \multicolumn{3}{c}{ Meydana Gelen Ölüm } \\
\hline Yıllar & Erkek & Kadın & Toplam & Erkek & Kadın & Toplam \\
\hline $\mathbf{2 0 0 8}$ & 69369 & 3594 & 72963 & 850 & 15 & 865 \\
$\mathbf{2 0 0 9}$ & 60754 & 3562 & 64316 & 1147 & 24 & 1171 \\
$\mathbf{2 0 1 0}$ & 59011 & 3892 & 62903 & 1.421 & 23 & 1444 \\
$\mathbf{2 0 1 1}$ & 65059 & 4168 & 69227 & 1668 & 32 & 1700 \\
$\mathbf{2 0 1 2}$ & 60090 & 5781 & 65871 & 735 & 9 & 744 \\
$\mathbf{2 0 1 3}$ & 170644 & 20745 & 191389 & 1336 & 24 & 1360 \\
$\mathbf{2 0 1 4}$ & 193192 & 28174 & 221366 & 1589 & 37 & 1.626 \\
$\mathbf{2 0 1 5}$ & 206922 & 34625 & 241547 & 1219 & 33 & 1252 \\
$\mathbf{2 0 1 6}$ & 241115 & 44953 & 286068 & 1369 & 36 & 1405 \\
$\mathbf{2 0 1 7}$ & 300770 & 58883 & 359653 & 1604 & 29 & 1633 \\
\hline Ort. & 192693 & 20838 & 163530 & 1293.8 & 26.2 & 1320 \\
\hline
\end{tabular}

Ülkemizin tüm sektörel birimleri genelinde elde edilen verilere bağıı olarak 10 yıllık süre içerisinde ortalama yıllık 163530 adet iş kazası meydana gelirken, iş kazasına maruz kalan erkek çalışanların ortalaması 192693, kadın çalışanların ortalaması ise 20838 olduğu görülmektedir. Yıllar içerisinde sürekli artış gösteren kaza sayısının, 2013 yılında yürürlüğe giren 6331 sayılı kanun ve kanunun gerektirdiği zorunluluklar dikkate alındığında değişim göstermediği dikkat çekmektedir. Belirlenen yıllar içinde meydana gelen ölüm rakamları dikkate alındığında ise yaklaşık olarak iki kat artışın olduğu ve erkek çalışanlar arasında meydana gelen ölüm rakamlarının kadın çalışanlara göre oldukça yüksek seviyelerde olduğu görülmektedir. Ülkemiz genelinde erkek çalışanların sayısının kadın çalışanlara göre fazla oluşu ve erkek çalışanların tehlike seviyesi yüksek alanlarda çalışmakta olduğu gerçeği bu farklılığın oluşmasında etken olarak kabul edilebilir (Gül ve ark. 2014; Aytaç ve ark. 2015; Serel ve Özdemir 2017). Ayrıca sanayileşme hamlesini tam olarak tamamlayamayan ülkemizde emek yoğun sektörlerin üretimde etkin oluşu, küçük ve orta ölçekli 
işletmelerin denetlenme sorunları iş kazası ve ölüm oranlarında artış sebebi olabilir. Türkiye genelini kapsayan ve tüm sektörel birimlerin dikkate alındığı değerler, Avrupa Birliğine uyum çerçevesinde 2013 yılında yürürlüğe giren 6331 sayılı yasanın gereklerinin yerine getirilmediğini göstermektedir. Özellikle yapılan hukuki düzenlemelerin kağıt üzerinde kalması ve iş yerlerinde uygulanma ve denetlenmesi noktasında oluşan eksiklikler bu sonuçların kaçınılmaz olarak karşımıza çıkmasına neden olmaktadır. İncelenen yıllar kapsamında imalat sanayi genelinde oluşan iş kazası ve meydana gelen ölümler ile ilgili veriler Çizelge 2'de görülmektedir.

Çizelge 2. İmalat sanayi genelinde iş kazası ve meydana gelen ölümler

\begin{tabular}{ccccccc}
\hline \multicolumn{3}{c}{ İ̧ Kazası } & \multicolumn{3}{c}{ Ölüm } \\
\hline Yıllar & Erkek & Kadın & Toplam & Erkek & Kadın & Toplam \\
\hline $\mathbf{2 0 0 8}$ & 32872 & 1874 & 34746 & 157 & 5 & 162 \\
$\mathbf{2 0 0 9}$ & 32131 & 2270 & 34401 & 86 & 3 & 89 \\
$\mathbf{2 0 1 0}$ & 31269 & 2397 & 33666 & 237 & 13 & 250 \\
$\mathbf{2 0 1 1}$ & 33083 & 2481 & 35564 & 296 & 13 & 309 \\
$\mathbf{2 0 1 2}$ & 34761 & 3521 & 38282 & 121 & 1 & 122 \\
$\mathbf{2 0 1 3}$ & 84311 & 10156 & 94467 & 254 & 7 & 261 \\
$\mathbf{2 0 1 4}$ & 94471 & 13090 & 107561 & 219 & 11 & 230 \\
$\mathbf{2 0 1 5}$ & 98827 & 14773 & 113600 & 207 & 8 & 215 \\
$\mathbf{2 0 1 6}$ & 109398 & 18221 & 127619 & 238 & 8 & 246 \\
$\mathbf{2 0 1 7}$ & 132114 & 23904 & 156018 & 287 & 9 & 296 \\
\hline Ort. & 68324 & 9269 & 77592 & & & \\
\hline
\end{tabular}

Ülkemiz imalat sanayi kapsamında 2017 yılı verileri dikte alındığında yaklaşık olarak 5 milyon çalışanın istihdam edildiği görülmektedir (Eurostat 2018). Meydana gelen iş kazaları incelendiğinde 2008 yılında 34746 adet olan iş kazası sayısının 2017 yılında 156018 olması ve ölüm rakamlarının iki kat yükselmesi üzüntü verici bir durumdur. Gerek Türkiye genelinde tüm sektörel alanlarda ve gerekse imalat sanayi düzeyinde 2013 yılı öncesi ve sonrasında oluşan rakamsal değişimler dikkat çekici bir artışı göstermektedir. Kazalarda oluşabilecek artış rakamlarının yanında, önceki yıllarda dikkate alınmayan, mevzuat gereği iş kazası ve buna bağlı ölüm olarak kabul edilmeyen olayların 2013 yılı sonrasında kayıt altına alınmasının etkili olduğu söylenebilir.

İmalat sanayi içinde yer alan ve orman ürünleri sanayi sektörünü oluşturan üç alt sektörel yapıda (A-Ağaç, ağaç ürünleri ve mantar imalatı; B-Kağıt ve kağıt ürünleri imalatı; C-Mobilya imalatı) yıllar genelinde meydana gelen iş kazası ve ölümler ile ilgili veriler Çizelge $3^{\prime}$ te gösterilmektedir. 2017 yılı sonu itibariyle üç alt sektörde 15-64 yaş arası kayıtlı çalışan sayısı 500000 civarındadır (Eurostat 2018). Sektör genelinde meydana gelen iş kazası ve ölüm rakamları özellikle istihdamın ve emek faktörünün daha yoğun bir kullanım alanı bulduğu A-Ağaç, ağaç ürünleri ve mantar imalatı ve C-Mobilya imalatı alt sektörel gruplarında yoğunlaşmaktadır. Ayrıca sektörün çalışma koşulları gereği kadın çalışan sayısının az olması, kadın çalışanlar arasında olan iş kazası ve ölüm rakamlarının düşük olmasına neden olmaktadır. 2008 yılında 2930 olan iş kazası sayısı 2012 yılına kadar önemli bir değişim göstermemiş ancak 2013 yılı ve sonrasında yaklaşık 4 kat artış göstererek 12310 sayısına yükselmiştir. Genel imalat sanayi içerisinde de aynı şekilde gözlemlenen bu durumun çalışan, işveren ya da iş ortamından kaynaklı olması kadar mevzuata uygun raporlama nedeni ile oluşabilecek olduğu yoruma açık bir konu niteliğindedir. 2017 yllı genelinde imalat sanayinde olan iş kazalarının \% 7.9'luk kesimi orman ürünleri sanayi sektörü genelinde oluşmuştur. Oluşan bu rakam sektör düzeyinde çalışma ortamında kullanılan kesici, ezici ve parçalayıcı aletlerle çalışmanın tehlikesini göstermesi bakımından önemlidir. İncelenen yıllar kapsamında ölüm rakamları içinde sadece 3 kadın çalışanın bulunması sektörde çalışan kadınların tehlikeli işlerde değil daha çok planlama ya da yan faaliyet alanlarında çalışıyor olduklarını göstermektedir. 2008 yılında 8 çalışan çalışma hayatını iş kazasına bağlı ölümle sonuçlandırmışken bu sayı 2017 yılında 34 adet olarak gerçekleşmiştir. İmalat sanayinde gerçekleşen ölüm rakamının yaklaşık \% $22^{\prime}$ lik kısmının orman ürünleri sanayinde gerçekleşiyor olması tehlikenin boyutunu net bir şeklide ortaya çıkarmaktadır.

\section{Avrupa Birliği Ülkelerinde İş Kazası ve Ölüm}

Ülkemiz geneli, imalat sanayi ve orman ürünleri sanayi sektörlerinin iş kazası ve ölüm rakamlarının Avrupa Birliği ülkeleri ile karşılaştırımasının amaçlandığı çalışmamızda Avrupa Birliği (AB) ülkeleri genelinde iş kazası ve ölüm istatistiklerinin 2016 yılı ile sınırlandırılmış olması 2017 yılı rakamlarının karşılaştırılmasına olanak sağlamamıştır. Avrupa Birliği genelinde çoğunluğu Almanya, İngiltere, Fransa, İtalya, İspanya ve Polonya da olmak üzere 2107 yılı sonu itibariyle yaklaşık 225 milyon 15-64 yaş arası çalışan istihdam edilmektedir (Eurostat 2018). Yapılan inceleme 
sonucunda $A B$ ülkeleri genelinde meydana gelen iş kazası ve ölüm rakamları Çizelge 4 ve 5 'te gösterilmektedir. İ̧̧ kazası istatistikleri incelendiğinde birlik içerisinde sektörel anlamda sahip olunan üretim gücünün iş kazası rakamlarına yansımış olduğu görülmektedir. İş kazasının en yoğun yaşanmış olduğu ülkeler Almanya, Fransa, İspanya, İtalya, İngiltere ve Portekiz'dir. Tüm yıllar genelinde Almanya ilk sıradaki yerini korurken yıllar içinde iş kazalarında oluşan azalmanın dikkat çekici boyutta olması önemlidir. Aynı durum İspanya ve İtalya içinde geçerlidir. Avrupa Birliğinde yer alan ülkeler içinde iş kazası sayısı Fransa, Hırvatistan, Litvanya, Letonya, Macaristan ve i̇sveç'te artış gösterirken diğer ülkelerde azalmıştır.

Çizelge 3. Orman ürünleri sanayi sektöründe iş kazası ve meydana gelen ölümler

\begin{tabular}{|c|c|c|c|c|c|c|c|}
\hline \multirow[b]{2}{*}{ Yillar } & \multirow[b]{2}{*}{ Alt Sektör } & \multicolumn{3}{|c|}{ İş Kazası } & \multicolumn{3}{|c|}{ Ölüm } \\
\hline & & Erkek & Kadın & Toplam & Erkek & Kadın & Toplam \\
\hline \multirow{4}{*}{2008} & A & 1111 & 15 & 1126 & 8 & 0 & 8 \\
\hline & B & 513 & 27 & 540 & 0 & 0 & 0 \\
\hline & C & 1246 & 14 & 1260 & 2 & 0 & 2 \\
\hline & Toplam & 2874 & 56 & 2930 & 10 & 0 & 10 \\
\hline \multirow{4}{*}{2009} & $A$ & 915 & 15 & 930 & 5 & 0 & 5 \\
\hline & B & 579 & 34 & 613 & 1 & 0 & 1 \\
\hline & C & 909 & 15 & 924 & 4 & 0 & 4 \\
\hline & Toplam & 2403 & 64 & 2467 & 10 & 0 & 10 \\
\hline \multirow{4}{*}{2010} & A & 867 & 14 & 881 & 11 & 0 & 11 \\
\hline & B & 560 & 27 & 587 & 2 & 0 & 2 \\
\hline & C & 869 & 10 & 879 & 4 & 0 & 4 \\
\hline & Toplam & 2296 & 51 & 2347 & 17 & 0 & 17 \\
\hline \multirow{4}{*}{2011} & $A$ & 991 & 18 & 1009 & 6 & 0 & 6 \\
\hline & B & 595 & 30 & 625 & 6 & 0 & 6 \\
\hline & C & 1308 & 16 & 1324 & 9 & 0 & 9 \\
\hline & Toplam & 2894 & 64 & 2958 & 21 & 0 & 21 \\
\hline \multirow{4}{*}{2012} & A & 907 & 28 & 935 & 4 & 0 & 4 \\
\hline & B & 595 & 40 & 635 & 1 & 0 & 1 \\
\hline & C & 1553 & 35 & 1588 & 4 & 0 & 4 \\
\hline & Toplam & 3055 & 103 & 3158 & 9 & 0 & 9 \\
\hline \multirow{4}{*}{2013} & A & 2209 & 62 & 2271 & 11 & 0 & 11 \\
\hline & B & 1595 & 103 & 1698 & 1 & 0 & 1 \\
\hline & C & 4344 & 135 & 4479 & 5 & 1 & 6 \\
\hline & Toplam & 8148 & 300 & 8448 & 17 & 1 & 18 \\
\hline \multirow{4}{*}{2014} & A & 2314 & 117 & 2431 & 8 & 0 & 8 \\
\hline & B & 1819 & 161 & 1930 & 6 & 0 & 6 \\
\hline & C & 4968 & 215 & 5183 & 9 & 0 & 9 \\
\hline & Toplam & 9101 & 493 & 9594 & 23 & 0 & 23 \\
\hline \multirow{4}{*}{2015} & A & 2368 & 177 & 2545 & 8 & 1 & 9 \\
\hline & B & 2018 & 170 & 2188 & 4 & 0 & 4 \\
\hline & C & 4829 & 239 & 5068 & 13 & 0 & 13 \\
\hline & Toplam & 9215 & 586 & 9801 & 25 & 1 & 26 \\
\hline \multirow{4}{*}{2016} & $A$ & 2611 & 203 & 2814 & 10 & 0 & 10 \\
\hline & B & 2361 & 182 & 2543 & 2 & 1 & 3 \\
\hline & C & 4725 & 288 & 5013 & 12 & 0 & 12 \\
\hline & Toplam & 9697 & 673 & 10370 & 24 & 1 & 25 \\
\hline \multirow{4}{*}{2017} & A & 2915 & 232 & 3147 & 7 & 0 & 7 \\
\hline & B & 2798 & 280 & 3078 & 11 & 0 & 11 \\
\hline & C & 5755 & 330 & 6085 & 16 & 0 & 16 \\
\hline & Toplam & 11468 & 842 & 12310 & 34 & 0 & 34 \\
\hline
\end{tabular}


Çizelge 4. Avrupa Birliği ülkeleri iş kazası

\begin{tabular}{|c|c|c|c|c|c|c|c|c|c|}
\hline Ülkeler & 2008 & 2009 & 2010 & 2011 & 2012 & 2013 & 2014 & 2015 & 2016 \\
\hline Belçika & 76514 & 66414 & 67263 & 65033 & 58418 & 56405 & 65587 & 63863 & 70674 \\
\hline Bulgaristan & 3037 & 2484 & 2331 & 2257 & 2278 & 2164 & 2246 & 2290 & 2188 \\
\hline Çek Cum. & 99478 & 66413 & 65109 & 42519 & 41306 & 44070 & 42306 & 42629 & 45282 \\
\hline Danimarka & 71288 & 61384 & 62523 & 57641 & 57761 & 55931 & 54157 & 50282 & 49439 \\
\hline Almanya & 943999 & 860797 & 930447 & 886849 & 854665 & 852061 & 847370 & 844541 & 862983 \\
\hline Estonya & 7228 & 5013 & 5556 & 5925 & 5847 & 6175 & 6288 & 6296 & 6354 \\
\hline İrlanda & 18078 & 11392 & 19294 & 16748 & 15284 & 18049 & 18115 & 16681 & 14088 \\
\hline Yunanistan & 24216 & 19879 & 15461 & 13490 & 11083 & 9676 & 3410 & 3749 & 3987 \\
\hline İspanya & 689131 & 535456 & 493789 & 445462 & 355811 & 370176 & 387439 & 413756 & 432052 \\
\hline Fransa & 637357 & 589994 & 592992 & 611797 & 587090 & 567407 & 724662 & 731120 & 749670 \\
\hline Hırvatistan & - & - & 11903 & 13568 & 11153 & 11709 & 11669 & 13145 & 13263 \\
\hline İtalya & 503431 & 447516 & 437821 & 405888 & 359363 & 329404 & 313312 & 295162 & 295967 \\
\hline GKRY & 2355 & 2218 & 2165 & 2005 & 1732 & 1529 & 1613 & 1592 & 1900 \\
\hline Litvanya & 1705 & 1155 & 1195 & 1353 & 1506 & 1707 & 1725 & 1709 & 1810 \\
\hline Letonya & 3156 & 2019 & 2266 & 2625 & 2808 & 3043 & 3120 & 3287 & 3541 \\
\hline Lüksemburg & 8133 & 6878 & 6983 & 7131 & 7163 & 7055 & 7183 & 7359 & 7152 \\
\hline Macaristan & 22337 & 18564 & 19989 & 17303 & 20477 & 18899 & 19491 & 20846 & 27434 \\
\hline Malta & 3213 & 2748 & 2751 & 2459 & 2529 & 2601 & 2632 & 2289 & 1818 \\
\hline Hollanda & 184121 & 177336 & 183005 & 170616 & 165433 & 152214 & 87964 & 72829 & 81165 \\
\hline Avusturya & 72990 & 64064 & 78413 & 70434 & 67025 & 64646 & 65418 & 61227 & 62902 \\
\hline Polonya & 96318 & 79546 & 85825 & 87741 & 86745 & 77339 & 76274 & 81880 & 84037 \\
\hline Portekiz & 147349 & 135102 & 130271 & 125912 & 113179 & 123137 & 130153 & 134378 & 135033 \\
\hline Romanya & 4559 & 3558 & 3722 & 3219 & 3281 & 3453 & 3396 & 3913 & 4188 \\
\hline Slovenya & 20186 & 17129 & 16367 & 14982 & 14297 & 12537 & 12314 & 12448 & 12162 \\
\hline Slovakya & 11614 & 9172 & 9126 & 8788 & 8483 & 8741 & 8552 & 9247 & 9814 \\
\hline Finlandiya & 57373 & 46306 & 48263 & 52902 & 46922 & 47432 & 44434 & 42069 & 41106 \\
\hline İsveç & 34413 & 31420 & 34201 & 34591 & 36098 & 36188 & 35296 & 36362 & 37858 \\
\hline İngiltere & 255468 & 265988 & 252597 & 245496 & 227676 & 243798 & 244948 & 237008 & 227165 \\
\hline Toplam & 3999047 & 3529945 & 3581628 & 3414734 & 3165413 & 3127546 & 3221074 & 3211957 & 3285032 \\
\hline
\end{tabular}

Çizelge 5'te $A B$ genelinde iş kazasına bağlı oluşan ölüm rakamları incelendiğinde 2008-2012 yılları arasında en yüksek ölüm rakamlarının İtalya'da gerçekleştiği görülürken, 2013-2016 yıllarında bu alanda liderlik Fransa'ya geçmektedir. Ayrıca yıllar kapsamında yüksek ölüm rakamlarının olduğu ülkeler arasında yalnızca Fransa ve Ingiltere'de ölüm rakamları yükselirken, diğer ülkelerde rakamlarda oluşan düşüş dikkat çeken bir diğer durumdur.

$A B$ üyesi ülkelerin imalat sanayi düzeyinde oluşan iş kazası ve ölüm rakamlarına ait istatistiksel veriler Çizelge 6 ve 7'de gösterilmektedir. Avrupa Birliği ülkeleri genelinde büyük çoğunluğu Almanya, İtalya, Polonya, İngiltere, Fransa ve Ispanya' da olmak üzere yaklaşık 35 milyon çalışan imalat sanayi alanında istihdam edilmektedir (Eurostat 2018). AB ülkeleri genelinde imalat sanayi alanında oluşan iş kazaları incelendiğinde Almanya'nın bu alanda önemli bir rakamsal üstünlüğe sahip olduğu dikkat çekmektedir. Diğer iş kazası yüksek seviyelerde yer alan ülkeler Fransa, İspanya, İtalya, Portekiz ve Polonya'dır. Incelenen yıllar kapsamında İngiltere, Macaristan, Litvanya, Estonya, Letonya ve İrlanda'da iş kazalarında yükselmeler görülmektedir. 
Çizelge 5. AB üyesi ülkeleri ölümlü iş kazaları

\begin{tabular}{|c|c|c|c|c|c|c|c|c|c|c|}
\hline Ülkeler & 2008 & & 2009 & 2010 & 2011 & 2012 & 2013 & 2014 & 2015 & 2016 \\
\hline Belçika & 96 & & 69 & 74 & 75 & 49 & 66 & 52 & 64 & 64 \\
\hline Bulgaristan & 151 & & 88 & 92 & 94 & 98 & 87 & 117 & 95 & 81 \\
\hline Çek Cum. & 174 & & 103 & 121 & 150 & 113 & 130 & 118 & 132 & 106 \\
\hline Danimarka & 47 & & 39 & 41 & 44 & 47 & 39 & 38 & 28 & 34 \\
\hline Almanya & 616 & & 489 & 567 & 507 & 516 & 444 & 500 & 450 & 413 \\
\hline Estonya & 21 & & 19 & 17 & 19 & 14 & 20 & 16 & 17 & 26 \\
\hline İrlanda & 51 & & 38 & 42 & 49 & 43 & 40 & 47 & 49 & 43 \\
\hline Yunanistan & 59 & & 31 & 32 & 37 & 26 & 22 & 28 & 28 & 33 \\
\hline İspanya & 529 & & 390 & 338 & 365 & 299 & 270 & 280 & 344 & 296 \\
\hline Fransa & 289 & & 557 & 537 & 559 & 576 & 553 & 589 & 595 & 595 \\
\hline Hırvatistan & - & & - & 35 & 38 & 54 & 29 & 26 & 30 & 33 \\
\hline İtalya & 780 & & 703 & 718 & 621 & 604 & 517 & 522 & 543 & 481 \\
\hline GKRY & 12 & & 9 & 19 & 5 & 9 & 9 & 5 & 4 & 5 \\
\hline Litvanya & 43 & & 32 & 25 & 34 & 35 & 31 & 41 & 26 & 38 \\
\hline Letonya & 79 & & 49 & 50 & 51 & 58 & 58 & 55 & 45 & 44 \\
\hline Lüksemburg & 10 & & 6 & 15 & 11 & 14 & 6 & 10 & 13 & 22 \\
\hline Macaristan & 117 & & 100 & 96 & 81 & 65 & 55 & 81 & 86 & 83 \\
\hline Malta & 3 & & 8 & 3 & 1 & 7 & 4 & 4 & 5 & 7 \\
\hline Hollanda & 106 & & 88 & 79 & 48 & 35 & 42 & 45 & 35 & 36 \\
\hline Avusturya & 170 & & 159 & 182 & 117 & 144 & 143 & 126 & 134 & 109 \\
\hline Polonya & 520 & & 406 & 446 & 404 & 350 & 277 & 263 & 304 & 243 \\
\hline Portekiz & 221 & & 213 & 204 & 192 & 169 & 160 & 160 & 161 & 138 \\
\hline Romanya & 497 & & 411 & 381 & 297 & 276 & 269 & 272 & 281 & 236 \\
\hline Slovenya & 27 & & 26 & 24 & 19 & 22 & 20 & 25 & 23 & 14 \\
\hline Slovakya & 80 & & 44 & 48 & 38 & 53 & 55 & 40 & 55 & 45 \\
\hline Finlandiya & 34 & & 32 & 37 & 33 & 36 & 22 & 35 & 35 & 35 \\
\hline İsveç & 68 & & 41 & 54 & 58 & 45 & 35 & 40 & 34 & 37 \\
\hline İngiltere & 157 & & 144 & 172 & 194 & 161 & 271 & 239 & 260 & 252 \\
\hline Toplam & 4957 & & 4294 & 4449 & 4141 & 3918 & 3674 & 3774 & 3876 & 3549 \\
\hline \multicolumn{11}{|c|}{ Çizelge 6. AB üyesi ülkeleri iş kazası - imalat sanayi } \\
\hline Ülkeler & 2008 & 2009 & 2010 & 2011 & 2012 & & & 2014 & 2015 & 2016 \\
\hline Belçika & 18465 & 14411 & 14108 & 13513 & 12205 & & & 10565 & 9991 & 10017 \\
\hline Bulgaristan & 1071 & 742 & 692 & 658 & 629 & & & 635 & 626 & 604 \\
\hline Çek Cum. & 55881 & 28691 & 32176 & 18730 & 17993 & & & 18676 & 19408 & 20388 \\
\hline Danimarka & 16054 & 10251 & 9225 & 8623 & 8124 & & & 7311 & 6704 & 6635 \\
\hline Almanya & 257419 & 212016 & 230779 & 227544 & 222931 & & & 212854 & 213524 & 214646 \\
\hline Estonya & 2253 & 1740 & 1971 & 2105 & 2174 & & & 2719 & 2637 & 2383 \\
\hline İrlanda & 1857 & 858 & 1562 & 2821 & 1824 & & & 2946 & 3130 & 2006 \\
\hline Yunanistan & 7889 & 6370 & 4425 & 3666 & 2856 & & & 752 & 797 & 802 \\
\hline İspanya & 155818 & 107757 & 98375 & 82292 & 63162 & & & 61978 & 66193 & 69592 \\
\hline Fransa & 111877 & 96566 & 92411 & 93034 & 86729 & & & 82701 & 80641 & 78683 \\
\hline Hırvatistan & - & - & 3639 & 4342 & 3826 & & & 3040 & 3032 & 3211 \\
\hline İtalya & 140225 & 108482 & 103489 & 92028 & 76846 & & & 68298 & 66076 & 65855 \\
\hline GKRY & 547 & 548 & 485 & 412 & 350 & & & 310 & 281 & 359 \\
\hline Litvanya & 473 & 266 & 294 & 374 & 416 & & & 542 & 512 & 549 \\
\hline Letonya & 935 & 569 & 604 & 692 & 774 & & & 860 & 950 & 1073 \\
\hline Lüksemburg & 874 & 779 & 790 & 808 & 773 & & & 696 & 765 & 732 \\
\hline Macaristan & 9219 & 6341 & 6921 & 6235 & 7183 & & & 7011 & 7756 & 10327 \\
\hline Malta & 877 & 672 & 668 & 615 & 624 & & & 597 & 495 & 366 \\
\hline Hollanda & 36918 & 21437 & 27618 & 22658 & 26128 & & & 12793 & 14205 & 16792 \\
\hline Avusturya & 18802 & 14166 & 16039 & 16079 & 15691 & & & 14247 & 13650 & 13849 \\
\hline
\end{tabular}


Çizelge 6 (Devamı). AB üyesi ülkeleri iş kazası - imalat sanayi

\begin{tabular}{lccccccccc}
\hline Ülkeler & $\mathbf{2 0 0 8}$ & $\mathbf{2 0 0 9}$ & $\mathbf{2 0 1 0}$ & $\mathbf{2 0 1 1}$ & $\mathbf{2 0 1 2}$ & $\mathbf{2 0 1 3}$ & $\mathbf{2 0 1 4}$ & $\mathbf{2 0 1 5}$ & $\mathbf{2 0 1 6}$ \\
\hline Polonya & 39070 & 28752 & 29782 & 31078 & 29379 & 26041 & 26357 & 27174 & 27947 \\
Portekiz & 50590 & 39649 & 36528 & 34745 & 33082 & 32407 & 34881 & 33045 & 33597 \\
Romanya & 1855 & 1346 & 1448 & 1256 & 1218 & 1311 & 1195 & 1375 & 1483 \\
Slovenya & 7858 & 5751 & 5539 & 5320 & 4907 & 4200 & 4027 & 4142 & 4118 \\
Slovakya & 5778 & 3837 & 3839 & 3745 & 3501 & 3332 & 3526 & 3676 & 3966 \\
Finlandiya & 13913 & 9336 & 9565 & 9685 & 8674 & 7670 & 7201 & 6213 & 5843 \\
İsveç & 6743 & 5044 & 5545 & 5553 & 5516 & 5169 & 5025 & 4945 & 5122 \\
Ingiltere & 27149 & 34051 & 32140 & 35215 & 36138 & 35664 & 35379 & 33491 & 32498 \\
\hline Toplam & 990410 & 760428 & 770657 & 723826 & 673653 & 649642 & 627122 & 625434 & 633443 \\
\hline
\end{tabular}

$A B$ üyesi ülkelerin imalat sanayilerinde meydana gelen ölümlü iş kazaları ile ilgili istatistiksel verilerin yer aldığı Çizelge 7 incelendiğinde yıllar ortalaması bakımından en yüksek ölüm ortalamasına İtalya, Fransa, Almanya,
Polonya ve Romanya'nın sahip olduğu görülmektedir. Fransa'nın ölüm rakamlarında yıllar içinde sahip olduğu yükseliş dikkat çekici boyuttadır.

Çizelge 7. AB üyesi ülkeleri ölümlü iş kazaları - imalat sanayi

\begin{tabular}{|c|c|c|c|c|c|c|c|c|c|c|c|}
\hline Ülkeler & 2008 & 2009 & 2010 & 2011 & 2012 & 2013 & 2014 & 2015 & 2016 & Toplam & Ort. \\
\hline Belçika & 18 & 12 & 10 & 9 & 10 & 11 & 15 & 16 & 5 & 106 & 21.2 \\
\hline Bulgaristan & 27 & 20 & 17 & 16 & 21 & 21 & 35 & 21 & 15 & 193 & 38.6 \\
\hline Çek Cum. & 33 & 26 & 25 & 32 & 22 & 27 & 22 & 28 & 19 & 234 & 46.8 \\
\hline Danimarka & 7 & 4 & 5 & 5 & 7 & 4 & 8 & 4 & 3 & 47 & 9.4 \\
\hline Almanya & 106 & 77 & 99 & 67 & 84 & 81 & 80 & 84 & 67 & 745 & 149 \\
\hline Estonya & 4 & 2 & 0 & 3 & 2 & 5 & 0 & 4 & 5 & 25 & 5 \\
\hline İrlanda & 7 & 1 & 2 & 2 & 0 & 1 & 3 & 3 & 2 & 21 & 4.2 \\
\hline Yunanistan & 19 & 5 & 2 & 6 & 6 & 3 & 5 & 8 & 5 & 59 & 11.8 \\
\hline İspanya & 90 & 59 & 62 & 57 & 50 & 42 & 27 & 73 & 50 & 510 & 102 \\
\hline Fransa & 46 & 88 & 76 & 70 & 91 & 71 & 79 & 79 & 89 & 689 & 137.8 \\
\hline Hırvatistan & - & - & 7 & 8 & 10 & 3 & 3 & 4 & 7 & 42 & 10.5 \\
\hline İtalya & 157 & 123 & 104 & 111 & 111 & 91 & 83 & 95 & 77 & 952 & 190.4 \\
\hline GKRY & 5 & 1 & 2 & 1 & 1 & 2 & 1 & 0 & 0 & 13 & 2.6 \\
\hline Litvanya & 6 & 7 & 4 & 7 & 6 & 6 & 6 & 6 & 5 & 53 & 10.6 \\
\hline Letonya & 13 & 9 & 9 & 7 & 3 & 9 & 5 & 6 & 10 & 71 & 14.2 \\
\hline Lüksemburg & 1 & 1 & 2 & 0 & 1 & 0 & 0 & 1 & 2 & 8 & 1.6 \\
\hline Macaristan & 18 & 11 & 16 & 14 & 8 & 5 & 15 & 12 & 12 & 111 & 22.2 \\
\hline Malta & 0 & 1 & 0 & 0 & 0 & 0 & 0 & 1 & 1 & 3 & 0.6 \\
\hline Hollanda & 12 & 14 & 10 & 7 & 8 & 5 & 13 & 11 & 8 & 88 & 17.6 \\
\hline Avusturya & 18 & 9 & 14 & 16 & 9 & 12 & 13 & 10 & 12 & 113 & 22.6 \\
\hline Polonya & 98 & 60 & 73 & 85 & 60 & 52 & 55 & 78 & 50 & 611 & 122.2 \\
\hline Portekiz & 27 & 29 & 27 & 30 & 33 & 25 & 25 & 17 & 26 & 239 & 47.8 \\
\hline Romanya & 90 & 96 & 83 & 74 & 57 & 59 & 49 & 49 & 40 & 597 & 119.4 \\
\hline Slovenya & 7 & 5 & 5 & 3 & 7 & 5 & 4 & 7 & 3 & 46 & 9.2 \\
\hline Slovakya & 16 & 8 & 11 & 9 & 12 & 13 & 7 & 8 & 6 & 90 & 18 \\
\hline Finlandiya & 3 & 1 & 8 & 1 & 5 & 4 & 4 & 3 & 4 & 33 & 6.6 \\
\hline İsveç & 10 & 11 & 9 & 11 & 7 & 8 & 3 & 4 & 2 & 65 & 13 \\
\hline İngiltere & 26 & 24 & 28 & 33 & 20 & 22 & 20 & 27 & 24 & 224 & 44.8 \\
\hline
\end{tabular}


$A B$ ülkeleri genelinde orman ürünleri sanayi sektörünü oluşturan üç alt sektörel grubun sahip olduğu iş kazaları ve ölüm rakamları ile ilgili yapılan istatistiksel inceleme sonucu oluşan çizelgeler aşağıda görülmektedir. Ağaç, ağaç ürünleri ve mantar imalatı alanında $A B$ genelinde 1 milyon üzeri 15-64 yaş arası çalışan istihdam edilmektedir. İstihdam oluşumunun yoğun olduğu ülkeler Almanya, Polonya, İtalya, Romanya, İngiltere ve Çek Cumhuriyetidir. Bu alanda meydana gelen iş kazalarına ait verilerin yer aldığı Çizelge 8 ve 9 incelendiğinde, iş kazaları bakımından Almanya'nın sahip olduğu rakamsal üstünlük net bir biçimde görülmektedir. 2008 yılında ağaç, ağaç ürünleri ve mantar imalatı alanında 8200 adet olan iş kazası 2016 yılında 13128 olarak kayıtlara geçmiştir. Bu alanda Almanya'nın sahip olduğu üretim gücü değerlendirme yapılırken inmal edilmemesi gereken bir konumda yer almaktadır. Almanya'yı iş kazası rakamları bakımından Fransa, İspanya, Portekiz, Polonya ve Avusturya takip etmektedir. Ağaç, ağaç ürünleri ve mantar imalatı alanında kaza sayılarında yıllar içerisinde artış ve azalışlar yaşanmasına karşın oluşan \% 25 düzeyindeki azalma dikkat çekmektedir. Orman ürünleri sanayi alanında sahip oldukları hammadde kaynağı bakımından dünya genelinde önemli söz sahibi olan Finlandiya ve İsveç'in sahip olduğu düşük iş kazası rakamları ve yıllar içinde oluşan azalma dikkat çekicidir. Oluşan iş kazalarının cinsiyete bağlı dağılımı incelendiğinde sektör genelinde erkek çalışan ağırlığı ve buna bağlı oluşan dağılım dikkat çekmektedir (Çizelge 9). AB ülkelerinde ortalama olarak 33021 adet erkek ve 3149 adet kadın çalışan belirtilen yıllar kapsamında kaza geçirmiş̧ir.

Çizelge 8. AB ülkeleri iş kazası -ağaç, ağaç ürünleri ve mantar imalatı

\begin{tabular}{|c|c|c|c|c|c|c|c|c|c|}
\hline Ülkeler & 2008 & 2009 & 2010 & 2011 & 2012 & 2013 & 2014 & 2015 & 2016 \\
\hline Belçika & 601 & 500 & 510 & 478 & 416 & 407 & 378 & 347 & 353 \\
\hline Bulgaristan & 50 & 33 & 27 & 36 & 27 & 33 & 24 & 31 & 25 \\
\hline Çek Cum. & 3168 & 2093 & 1887 & 1153 & 1027 & 906 & 894 & 890 & 957 \\
\hline Danimarka & 585 & 440 & 364 & 315 & 308 & 279 & 253 & 289 & 312 \\
\hline Almanya & 8200 & 6610 & 6676 & 6622 & 6642 & 14568 & 12615 & 12425 & 13128 \\
\hline Estonya & 487 & 400 & 486 & 556 & 566 & 711 & 612 & 710 & 580 \\
\hline İrlanda & 70 & 27 & 64 & 78 & 48 & 86 & 92 & 101 & 57 \\
\hline Yunanistan & 304 & 199 & 114 & 152 & 73 & 47 & 15 & 13 & 11 \\
\hline İspanya & 6980 & 4464 & 4063 & 3477 & 2635 & 2292 & 2413 & 2547 & 2675 \\
\hline Fransa & 5416 & 4466 & 4355 & 4554 & 4150 & 3956 & 4584 & 4419 & 4368 \\
\hline Hırvatistan & - & - & 220 & 498 & 419 & 247 & 274 & 285 & 303 \\
\hline İtalya & 6950 & 5764 & 5311 & 4608 & 3846 & 3470 & 3155 & 3116 & 2971 \\
\hline GKRY & 56 & 54 & 34 & 29 & 21 & 17 & 20 & 12 & 14 \\
\hline Litvanya & 183 & 103 & 119 & 152 & 143 & 166 & 195 & 187 & 209 \\
\hline Letonya & 107 & 79 & 58 & 60 & 82 & 114 & 135 & 136 & 156 \\
\hline Lüksemburg & 30 & 20 & 19 & 16 & 23 & 29 & 16 & 23 & 27 \\
\hline Macaristan & 283 & 161 & 189 & 176 & 175 & 162 & 166 & 181 & 246 \\
\hline Malta & 11 & 12 & 6 & 6 & 20 & 7 & 8 & 11 & 5 \\
\hline Hollanda & 344 & 986 & 767 & 424 & 600 & 219 & 612 & 1301 & 325 \\
\hline Avusturya & 2001 & 1370 & 1551 & 1599 & 1596 & 1511 & 1402 & 1356 & 1419 \\
\hline Polonya & 2623 & 1833 & 2067 & 2068 & 1758 & 1618 & 1630 & 1633 & 1647 \\
\hline Portekiz & 3662 & 3040 & 3047 & 2625 & 2580 & 2275 & 2615 & 2696 & 1938 \\
\hline Romanya & 155 & 133 & 135 & 161 & 134 & 154 & 131 & 169 & 128 \\
\hline Slovenya & 525 & 364 & 402 & 368 & 291 & 263 & 276 & 302 & 313 \\
\hline Slovakya & 410 & 256 & 247 & 205 & 153 & 160 & 167 & 147 & 160 \\
\hline Finlandiya & 1727 & 1113 & 1280 & 1258 & 1012 & 878 & 794 & 679 & 719 \\
\hline İsveç & 684 & 473 & 526 & 497 & 500 & 465 & 417 & 489 & 520 \\
\hline İngiltere & 1166 & 1269 & 1116 & 1273 & 1260 & 1265 & 1210 & 1425 & 1431 \\
\hline Toplam & 46778 & 36262 & 35640 & 33444 & 30505 & 36305 & 35103 & 35920 & 34997 \\
\hline
\end{tabular}


Çizelge 9. AB ülkeleri iş kazası (ağaç, ağaç ürünleri ve mantar imalatı, 2008-2016 ortalama)

\begin{tabular}{|c|c|c|c|c|c|c|c|c|}
\hline Ülkeler & Erkek & Kadın & Ülkeler & Erkek & Kadın & Ülkeler & Erkek & Kadın \\
\hline Belçika & 433 & 10 & Hırvatistan & 270 & 50 & Polonya & 1614 & 261 \\
\hline Bulgaristan & 27 & 5 & İtalya & 4146 & 208 & Portekiz & 2360 & 359 \\
\hline Çek Cum. & 1206 & 235 & GKRY & 27 & 1 & Romanya & 121 & 23 \\
\hline Danimarka & 300 & 48 & Litvanya & 130 & 32 & Slovenya & 284 & 61 \\
\hline Almanya & 8995 & 725 & Letonya & 82 & 21 & Slovakya & 171 & 40 \\
\hline Estonya & 364 & 204 & Lüksemburg & 22 & 0 & Finlandiya & 938 & 113 \\
\hline İrlanda & 68 & 1 & Macaristan & 164 & 29 & İsveç & 454 & 54 \\
\hline Yunanistan & 97 & 6 & Malta & 9 & 0 & İngiltere & 1.241 & 28 \\
\hline İspanya & 3308 & 197 & Hollanda & 620 & 0 & & & \\
\hline Fransa & 4144 & 330 & Avusturya & 1426 & 108 & & & \\
\hline
\end{tabular}

Avrupa Birliği genelinde kağıt ve kağıt ürünleri imalatı alanında yaklaşık 540000 çalışan istihdam edilmektedir. Çalışanların önemli bir kısmı Almanya, İtalya, İspanya, Fransa, Portekiz ve İngiltere'de istihdam edilmektedir
(Eurostat 2018). Kağıt ve kağıt ürünleri imalatı alanında oluşan iş kazası sayıları ve kazaların cinsiyete göre dağılımları Çizelge 10 ve 11 'de verilmektedir.

Çizelge 10. AB ülkeleri iş kazası kağıt ve kağıt ürünleri imalatı

\begin{tabular}{|c|c|c|c|c|c|c|c|c|c|}
\hline Ülkeler & 2008 & 2009 & 2010 & 2011 & 2012 & 2013 & 2014 & 2015 & 2016 \\
\hline Belçika & 385 & 321 & 319 & 290 & 257 & 227 & 214 & 215 & 226 \\
\hline Bulgaristan & 20 & 14 & 18 & 12 & 14 & 11 & 18 & 13 & 7 \\
\hline Çek Cum. & 824 & 491 & 453 & 276 & 283 & 313 & 306 & 359 & 359 \\
\hline Danimarka & 200 & 153 & 162 & 84 & 127 & 99 & 114 & 106 & 87 \\
\hline Almanya & 6008 & 4173 & 5063 & 4211 & 302 & 6828 & 5114 & 7042 & 4525 \\
\hline Estonya & 68 & 45 & 39 & 71 & 32 & 63 & 39 & 46 & 25 \\
\hline İrlanda & 31 & 11 & 18 & 62 & 24 & 32 & 46 & 39 & 20 \\
\hline Yunanistan & 240 & 209 & 149 & 120 & 108 & 85 & 32 & 40 & 26 \\
\hline İspanya & 3270 & 2289 & 2041 & 1686 & 1254 & 1270 & 1290 & 1383 & 1393 \\
\hline Fransa & 2741 & 2335 & 2289 & 2239 & 2006 & 1925 & 1875 & 1830 & 1851 \\
\hline Hırvatistan & - & - & 70 & 70 & 40 & 45 & 37 & 36 & 47 \\
\hline İtalya & 2869 & 2335 & 2273 & 1914 & 1669 & 1554 & 1476 & 1491 & 1441 \\
\hline GKRY & 5 & 9 & 8 & 5 & 8 & 3 & 8 & 3 & 5 \\
\hline Litvanya & 2 & 6 & 4 & 6 & 9 & 5 & 4 & 4 & 2 \\
\hline Letonya & 15 & 10 & 14 & 12 & 13 & 11 & 18 & 28 & 24 \\
\hline Lüksemburg & 7 & 1 & 3 & 5 & 6 & 3 & 1 & 1 & 1 \\
\hline Macaristan & 196 & 167 & 166 & 132 & 137 & 118 & 146 & 170 & 241 \\
\hline Malta & 13 & 13 & 5 & 5 & 5 & 13 & 11 & 9 & 10 \\
\hline Hollanda & 757 & 389 & 975 & 512 & 482 & 0 & 383 & 353 & 260 \\
\hline Avusturya & 379 & 333 & 381 & 338 & 363 & 346 & 317 & 289 & 310 \\
\hline Polonya & 828 & 653 & 679 & 739 & 705 & 596 & 688 & 714 & 710 \\
\hline Portekiz & 666 & 560 & 565 & 507 & 557 & 545 & 624 & 643 & 585 \\
\hline Romanya & 30 & 17 & 26 & 15 & 19 & 18 & 24 & 25 & 41 \\
\hline Slovenya & 183 & 179 & 131 & 127 & 135 & 110 & 84 & 107 & 97 \\
\hline Slovakya & 85 & 55 & 58 & 63 & 49 & 83 & 44 & 46 & 55 \\
\hline Finlandiya & 763 & 481 & 500 & 393 & 314 & 255 & 207 & 177 & 175 \\
\hline İsveç & 425 & 338 & 430 & 383 & 374 & 314 & 330 & 300 & 306 \\
\hline İngiltere & 663 & 842 & 676 & 739 & 832 & 817 & 758 & 741 & 597 \\
\hline Toplam & 21673 & 16429 & 17515 & 15016 & 10124 & 15689 & 14208 & 16210 & 13426 \\
\hline
\end{tabular}


Almanya, Fransa, İtalya ve İspanya'nın iş kazası istatistikleri birlik genelinde yer alan birçok ülkenin oldukça üzerindedir. Avrupa Birliği ülkelerinin tamamına yakınında kağıt üretimi alanında yaşanan iş kazalarında ciddi düşüşler yaşanmış olmasına karşın kaza sayıları az olan Letonya, Macaristan ve Romanya'da küçük yükselmeler görülmektedir. İş kazası sayısında \% 38 oranında oluşan azalma bu alanda iş sağlığı ve güvenliğine verilen önemin göstergesi niteliğindedir. Çizelge $11^{\prime} \mathrm{e}$ göre, kağıt ve kağıt ürünleri imalatı alanında $A B$ ülkelerinde 8 yıllık süre kapsamında ortalama olarak 13163 erkek çalışan, 2436 adet kadın çalışan kaza geçirmiştir.

Çizelge 11. AB ülkeleri iş kazası (kağıt ve kağıt ürünleri imalatı, 2008-2016 ortalama)

\begin{tabular}{|c|c|c|c|c|c|c|c|c|}
\hline Ülkeler & Erkek & Kadın & Ülkeler & Erkek & Kadın & Ülkeler & Erkek & Kadın \\
\hline Belçika & 234 & 39 & Hırvatistan & 42 & 7 & Polonya & 557 & 145 \\
\hline Bulgaristan & 10 & 4 & İtalya & 1727 & 164 & Portekiz & 487 & 97 \\
\hline Çek Cum. & 292 & 116 & GKRY & 5 & 1 & Romanya & 18 & 6 \\
\hline Danimarka & 99 & 26 & Litvanya & 4 & 1 & Slovenya & 104 & 24 \\
\hline Almanya & 3993 & 812 & Letonya & 11 & 5 & Slovakya & 48 & 12 \\
\hline Estonya & 30 & 18 & Lüksemburg & 3 & 0 & Finlandiya & 308 & 55 \\
\hline İrlanda & 25 & 6 & Macaristan & 118 & 46 & İsveç & 286 & 69 \\
\hline Yunanistan & 100 & 12 & Malta & 9 & 1 & İngiltere & 650 & 91 \\
\hline İspanya & 1498 & 266 & Hollanda & 428 & 29 & & & \\
\hline Fransa & 1773 & 348 & Avusturya & 304 & 36 & & & \\
\hline
\end{tabular}

Mobilya imalatı alanında AB ülkeleri genelinde çoğunluğu İtalya, Almanya, Polonya ve Romanya'da olmak üzere 1230000 çalışan istihdam edilmektedir (Eurostat 2018). Avrupa Birliği ülkelerinde 2008-2016 yılları kapsamında mobilya imalatı alanında meydana gelen iş kazaları ve cinsiyete göre dağılım Çizelge 12 ve $13^{\prime}$ te gösterilmektedir. Diğer alt sektörler seviyesinde Almanya'nın sahip olduğu iş kazası değerlerindeki liderlik mobilya üretimi alanında da kendini göstermektedir. Almanya sahip olduğu üretim gücünün bir bedeli olarak iş kazalarında Avrupa birinciliğinde ısrarlı bir konumdadır. Incelenen yıllar kapsamında \% 130 düzeyinde bir azalma göstermesine karşın bu alanda ilk sırada yerini korumaktadır. Almanya'yı İtalya, Polonya, Portekiz, İspanya ve Fransa takip etmektedir.

Çizelge 12. AB ülkeleri iş kazası - mobilya imalatı

\begin{tabular}{|c|c|c|c|c|c|c|c|c|c|}
\hline Ülkeler & 2008 & 2009 & 2010 & 2011 & 2012 & 2013 & 2014 & 2015 & 2016 \\
\hline Belçika & 636 & 530 & 560 & 472 & 408 & 362 & 379 & 346 & 377 \\
\hline Bulgaristan & 62 & 25 & 32 & 32 & 46 & 28 & 34 & 23 & 23 \\
\hline Çek Cum. & 1377 & 816 & 772 & 526 & 462 & 447 & 496 & 438 & 482 \\
\hline Danimarka & 534 & 345 & 275 & 265 & 209 & 180 & 217 & 170 & 238 \\
\hline Almanya & 13069 & 12619 & 12268 & 12023 & 10466 & 5204 & 4967 & 5265 & 5177 \\
\hline Estonya & 151 & 171 & 171 & 155 & 165 & 188 & 229 & 217 & 200 \\
\hline İrlanda & 25 & 6 & 14 & 62 & 37 & 38 & 32 & 21 & 28 \\
\hline Yunanistan & 443 & 310 & 247 & 155 & 79 & 54 & 22 & 11 & 20 \\
\hline İspanya & 6367 & 4016 & 3594 & 2969 & 2087 & 1755 & 1796 & 1842 & 2028 \\
\hline Fransa & 3599 & 2875 & 2756 & 2714 & 2322 & 2051 & 1855 & 1782 & 1798 \\
\hline Hırvatistan & - & - & 190 & 150 & 169 & 146 & 146 & 96 & 125 \\
\hline İtalya & 6151 & 4917 & 4539 & 3785 & 2958 & 2739 & 2645 & 2538 & 2436 \\
\hline GKRY & 36 & 23 & 24 & 22 & 18 & 13 & 11 & 5 & 8 \\
\hline Litvanya & 19 & 11 & 14 & 14 & 19 & 33 & 25 & 22 & 29 \\
\hline Letonya & 101 & 62 & 94 & 115 & 131 & 151 & 147 & 196 & 172 \\
\hline Lüksemburg & 9 & 12 & 8 & 9 & 9 & 10 & 7 & 8 & 11 \\
\hline Macaristan & 237 & 202 & 184 & 136 & 142 & 154 & 135 & 159 & 202 \\
\hline
\end{tabular}


Çizelge 12 (Devamı). AB ülkeleri iş kazası - mobilya imalatı

\begin{tabular}{lccccccccc}
\hline Ülkeler & $\mathbf{2 0 0 8}$ & $\mathbf{2 0 0 9}$ & $\mathbf{2 0 1 0}$ & $\mathbf{2 0 1 1}$ & $\mathbf{2 0 1 2}$ & $\mathbf{2 0 1 3}$ & $\mathbf{2 0 1 4}$ & $\mathbf{2 0 1 5}$ & $\mathbf{2 0 1 6}$ \\
\hline Malta & 64 & 65 & 55 & 34 & 42 & 38 & 32 & 26 & 32 \\
Hollanda & 1641 & 525 & 932 & 289 & 238 & 1527 & 1169 & 345 & 411 \\
Avusturya & 1233 & 928 & 976 & 912 & 840 & 824 & 812 & 785 & 748 \\
Polonya & 2912 & 2285 & 2405 & 2400 & 2293 & 1947 & 1959 & 2135 & 2200 \\
Portekiz & 4197 & 3466 & 3353 & 2692 & 2413 & 2140 & 2341 & 2090 & 2189 \\
Romanya & 164 & 100 & 91 & 83 & 84 & 102 & 99 & 101 & 149 \\
Slovenya & 406 & 321 & 269 & 221 & 170 & 135 & 101 & 106 & 134 \\
Slovakya & 344 & 207 & 199 & 172 & 162 & 147 & 161 & 168 & 178 \\
Finlandiya & 369 & 233 & 241 & 233 & 232 & 151 & 150 & 116 & 158 \\
İsveç & 170 & 132 & 144 & 149 & 144 & 135 & 122 & 127 & 112 \\
Ingiltere & 842 & 1024 & 916 & 860 & 766 & 692 & 751 & 769 & 941 \\
\hline Toplam & 45158 & 36226 & 35323 & 31649 & 27111 & 21391 & 20840 & 19907 & 20606 \\
\hline
\end{tabular}

Mobilya imalatı alanında kaza geçirenlerin cinsiyetlerinin incelendiği Çizelge 13'te, 8 yıllık ortalama değerler dikkate alındığında AB ülkelerinde bu alanda ortalama 25692 erkek çalışanın ve 3031 kadın çalışanın kaza geçirmiş olduğu görülmektedir.

Çizelge 13. AB ülkeleri iş kazası (mobilya imalatı, 2008-2016 ortalama)

\begin{tabular}{lcclccccc}
\hline Ülkeler & Erkek & Kadın & Ülkeler & Erkek & Kadın & Ülkeler & Erkek & Kadın \\
\hline Belçika & 419 & 34 & Hırvatistan & 121 & 25 & Polonya & 1833 & 449 \\
Bulgaristan & 26 & 8 & İtalya & 3314 & 321 & Portekiz & 2401 & 363 \\
Çek Cum. & 510 & 136 & GKRY & 17 & 1 & Romanya & 88 & 20 \\
Danimarka & 216 & 53 & Litvanya & 16 & 4 & Slovenya & 166 \\
Almanya & 8383 & 624 & Letonya & 95 & 35 & Slovakya & 147 \\
Estonya & 118 & 66 & Lüksemburg & 9 & 0 & Finlandiya & 177 \\
İrlanda & 28 & 2 & Macaristan & 144 & 29 & İsveç & 41 \\
Yunanistan & 144 & 5 & Malta & 43 & 1 & İngiltere & 777 \\
İspanya & 2733 & 206 & Hollanda & 766 & 20 & & 28 \\
Fransa & 2083 & 334 & Avusturya & 809 & 86 & & 62 \\
\hline
\end{tabular}

Avrupa Birliği ülkelerin Orman Ürünleri Sanayi alanında 8 yıllık iş kazasına bağlı oluşan ölüm rakamları incelendiğinde (Çizelge 14) ilk sırada 137 ölümle Romanya'nın yer aldığı görülmektedir. Romanya'yı 112 ölümle Polonya, 104 ölümle İtalya ve 83 ölümle Almanya izlemektedir. İş kazasına bağlı ölümlerin \% 65.56'sı ağaç ve ağaç ürünleri imalatı alanında görülürken \% 17.46 'sı mobilya imalatı alanında görülmüştür.

Çizelge 14. Alt sektörel gruplar düzeyinde $A B$ üyesi ülkeler ölümlü iş kazaları (2008-2016 toplam)

\begin{tabular}{|c|c|c|c|c|}
\hline Ülkeler & $\begin{array}{c}\text { Ağaç, ağaç ürünleri ve } \\
\text { mantar imalatı }\end{array}$ & $\begin{array}{c}\text { Kağıt ve Kağıt Ürünleri } \\
\text { İmalatı }\end{array}$ & Mobilya İmalatı & Toplam \\
\hline Belçika & 6 & 1 & 1 & 8 \\
\hline Bulgaristan & 14 & 1 & 3 & 18 \\
\hline Çek Cum. & 21 & 5 & 4 & 30 \\
\hline Danimarka & 3 & 1 & 0 & 4 \\
\hline Almanya & 47 & 21 & 15 & 83 \\
\hline Estonya & 4 & 0 & 0 & 4 \\
\hline İrlanda & 3 & 0 & 0 & 3 \\
\hline Yunanistan & 3 & 3 & 1 & 7 \\
\hline İspanya & 20 & 15 & 11 & 46 \\
\hline Fransa & 31 & 19 & 9 & 59 \\
\hline Hırvatistan & 3 & 1 & 1 & 5 \\
\hline
\end{tabular}


Çizelge 14 (Devamı). Alt sektörel gruplar düzeyinde AB üyesi ülkeler ölümlü iş kazaları (2008-2016 toplam)

\begin{tabular}{|c|c|c|c|c|}
\hline Ülkeler & $\begin{array}{l}\text { Ağaç, ağaç ürünleri ve } \\
\text { mantar imalatı }\end{array}$ & $\begin{array}{c}\text { Kağıt ve Kağıt Ürünleri } \\
\text { İmalatı }\end{array}$ & Mobilya İmalatı & Toplam \\
\hline İtalya & 53 & 18 & 33 & 104 \\
\hline GKRY & 1 & 0 & 0 & 1 \\
\hline Litvanya & 23 & 0 & 1 & 24 \\
\hline Letonya & 17 & 3 & 7 & 27 \\
\hline Lüksemburg & 1 & 0 & 0 & 1 \\
\hline Macaristan & 9 & 2 & 4 & 15 \\
\hline Malta & 1 & 0 & 0 & 1 \\
\hline Hollanda & 2 & 2 & 1 & 5 \\
\hline Avusturya & 16 & 1 & 1 & 18 \\
\hline Polonya & 77 & 17 & 18 & 112 \\
\hline Portekiz & 26 & 4 & 5 & 35 \\
\hline Romanya & 108 & 7 & 22 & 137 \\
\hline Slovenya & 5 & 0 & 2 & 7 \\
\hline Slovakya & 14 & 2 & 0 & 16 \\
\hline Finlandiya & 3 & 5 & 0 & 8 \\
\hline İsveç & 10 & 7 & 1 & 18 \\
\hline İngiltere & 16 & 4 & 3 & 23 \\
\hline Toplam & 537 & 139 & 143 & 819 \\
\hline
\end{tabular}

\section{SONUÇ ve ÖNERILER}

Insan sağlığı ve onuruna önem veren ve çalışanların sağlıklı ve güvenli bir çalışma ortamında çalışması endişesi taşıyan tüm dünya ülkelerinin temel kaygısı iş sağlığı ve güvenliğine yönelik tedbirleri almak ve güvenli bir çalışma ortamında üretim faaliyetlerini sürdürmektir. Yapılan tüm düzenlemeler ve alınan tüm tedbirlere karşın iş kazası ve buna bağlı gerçekleşen ölüm vakalarının çalışma ortamlarından tamamen uzaklaştırılması mümkün olmamaktadır. Dünya genelinde gelişmiş ülkeler sıralamasında ilk sıralarda yer alan $A B$ üyesi ülkeler çalışma hayatına yönelik yasal düzenlemelerin yapıldığı gereken tedbirlerin alınmaya çalışıldığı bir yapıya sahiptir. Ülkemiz ve Avrupa Birliği ülkelerinde genel, imalat sanayi ve orman ürünleri sanayi kapsamında meydana gelen iş kazaları ve ölüm rakamlarının yıllık değişimlere bağlı olarak incelenmesinin amaçlandığı bu çalışmada, sektörel olarak ülkeler arası karşılaştırmalar yapılmıştır. Genel çalışan sayısı bakımından ülkemiz çalışan sayısından yaklaşık olarak 8 kat, imalat sanayi kapsamındaki çalışan sayısından 7 kat ve orman ürünleri sanayi alanında çalışan sayısından 6 kat kazla çalışan istihdam eden Avrupa Birliği ülkeleri incelenen yıllar kapsamında iş kazası ve ölüm rakamlarını azaltma eğilimi içinde olduğu görülmektedirler.
Avrupa Birliğine adaylık sürecinde uyum yasaları çerçevesinde imzalanan sözleşmeler ve yapılan yasal düzenlemelerin ülkemiz açısından etkili sonuçlar oluşturmadığı bulunmuştur. AB ülkeleri genelinde tüm alanlarda iş kazaları ve ölüm düzeylerinde görülen azalma karşısında ülkemiz genel, imalat sanayi ve orman ürünleri sanayi alanlarında artış gösteren rakamlar çalışanlara yönelik yasal düzenlemelerin yeterli olmadığını, kuralları getiren ve denetleyen konumunda yer alan birimlerin görevlerini tam anlamıyla yerine getirmediklerini ve kurallara uyması gereken çalışanların kuralları ciddiye almadıklarını göstermektedir. Gelişmiş ülkeler işçi sağlığı ve güvenliği alanında ilerleme kaydederken bizim sürekli kaza ve ölüm rakamları ile ilgili almamı gereken ama almamış olduğumuz tedbirleri karşımıza çıkarmaktadır. Tüm olumsuzlukların giderilmesinde temel etmen olan eğitim, yerine getirilmesi gereken bir işlem olarak değil, ciddiye alınması gereken bir faaliyet olarak çalışanlara verilmelidir. Çalışanların işçi sağlığı ve güvenliğine yönelik tüm eğitimlere eksiksiz katılmaları ve gerekirse katılım gösterilen eğitim karşılığı ücret almaları sağlanmalıdır. Çalışanların hak ettikleri ve adil düzeyde bir ücretle çalışma hayatında yer almaları yapacakları üretim faaliyetini dolayısıyla kendilerine önem vermelerine neden olacaktır. Ayrıca çalışanların iş güvenliği alanında 
kurallara uygun davranış göstermeleri konusunda teşvik edilmesi ve sonrasında ödüllendirilmeleri kaza ve ölüm rakamlarının azalmasına katkı sağlayacaktır.

\section{KAYNAKLAR}

Akyüz KC (1995) Trabzon ilindeki küçük ve orta ölçekli orman ürünleri sanayi işletmelerinin sosyo-ekonomik tahlili. Karadeniz Teknik Üniversitesi Fen Bilimleri Enstitüsü Doktora Tezi, Trabzon, 1-17 s.

Aytaç S, Özok AF, Yamankaradeniz N, Akalp G, Çankaya O, Gökçe A, Tüfekçi U, Parçalı A, Snaet C (2015) Metal endüstrisinde çalışan kadın işçiler arasında algılanan risk faktörleri. Süleyman Demirel Üniversitesi Mühendislik Bilimleri ve Tasarım Dergisi 3(3):141-148.

Erginel N, Toptancı Ş (2017) İş kazası verilerinin olasılık dağılımları ile modellenmesi. Mühendislik Bilimleri ve Tasarım Dergisi 5(Özel Sayı):201-212.

Eurostat (2018) https://ec.europa.eu/eurostat/data/database. Accessed 1 Aralık 2018.

Gül H, Yalçınoğlu N, Atlı ZC (2014). Türkiye'de çalışma yaşamında kadını konumu ve sorunları. TAF Preventive Medicine Bulletin 13(2):169176.

Güzel A, Okur AR, Caniklioğlu N (2016) Sosyal güvenlik hukuku. Beta Yayıncılık, İstanbul.

Hsu CF (2011) An analysis of the new global strategy and action on occupational safety and health of the international labour organization. Journal of Occupational Safety and Health 19:183198.

Kılkış I (2016) İ̧s sağıığı ve güvenliği. Dora Basım-Yayın Ltd. Şti, Bursa.

Koçer şÖ (2014) Almanya Federal Cumhuriyeti sosyal güvenlik sistemi ve sistem içerisinde sosyal sigorta uygulamaları. TC Çalışma ve Sosyal Güvenlik Bakanlığı Uzmanlık Tezi, Ankara, 3-5 s.

Korkmaz A, Avsallı H (2012) Çalışma hayatında yeni bir dönem:6331 sayılı iş sağlığı ve güvenliği yasası. SDÜ Fen Edebiyat Fakültesi Sosyal Bilimler Dergisi 26:153-167.

Korkut G, Tetik A (2013) 6331 Sayılı iş sağlığı ve güvenliği Kanunu'nun getirdiği yenilikler ve temel sorunlar. Süleyman Demirel Üniversitesi, İktisadi ve İdari Bilimler Fakültesi Dergisi 18(3):455474.

Öçal M, Çiçek Ö (2017) Türkiye ve Avrupa Birliğinde iş kazası verilerinin karşılaştırmalı analizi. Emek ve Toplum 6(16):616-637.

Serel H, Özdemir BS (2017) Türkiye'de kadın istihdamı ve ekonomik büyüme ilişkisi. Yönetim ve Ekonomi Araştırmaları Dergisi 15(3):132-148.

SGK (2018) Sosyal sigortalar ve genel sağlık sigortası Kanunu (2006). Resmi Gazete Kanun No: 5510.

Süzek S (1985) İ̧ güvenliği hukuku. Savaş Yayınları, Ankara.

Şahin S (2010) OHSAS işçi sağlığı ve iş güvenliğinde insan kaynaklarının yeri ve önemi. Sakarya Üniversitesi Sosyal Bilimler Enstitüsü Yüksek Lisans Tezi, Sakarya, 25 s.

Tülü M (2014). İş sağlığı ve güvenliği hizmetlerinde isG profesyonellerinin algı ve beklentileri. TC Çalışma ve Sosyal Güvenlik Bakanlığı İş Sağlığı ve Güvenliği Genel Müdürlüğü İş Sağlığı ve Güvenliği Uzmanlık Tezi, Ankara.

Üçüncü K (2015) 2014 yılı SGK iş kazası istatistiklerinin analizi.
http://www.isteguvenlik.tc/2014\%20SGK\%20Analiz.pdf. Erişim 20 Temmuz 2019.

Yılmaz A (2017) Sosyal güvenlik hukukunda iş kazası kavramı: Kıta Avrupası ve Anglosakson hukuk sistemlerinden birer örnek ile Türk hukuku karşılaştırması. Sosyal Güvence Dergisi 6(11):107-127. 